\title{
СОЦАЛЬНА ПОЛІТИКА
}

УДК 332.85(477)

\section{Ю.М.МАНЦЕВИЧ,}

д-р екон. наук, доцент, завідувач секретаріату Комітету

Верховної Ради України з питань будівництва,

містобудування і житлово-комунального господарства та регіональної політики

\section{I.В.ЗАПАТРІНА,}

д-р екон. наук, проф.кафедри фінансів

Київського Національного торговельно-економічного

інституту, Голова Правління Українського

центру сприяння розвитку публічно-приватного партнерства

\section{РОЗВИТОК ДЕРЖАВНОЇ ПІДТРИМКИ ЖИТЛОВИХ ПРОГРАМ В УКРАЇНІ}

Стаття присвячена аналізу економічних наслідків та умов функціонування ринку житла в результаті зміни законодавства України. На основі оцінки перерозподілу грошових потоків зроблено висновок про недостатню ефективність житлової політики, орієнтованої на збільшення кількості приватних власників. Автори вважають, що значного економічного ефекту можна досягти за рахунок активізації соціально орієнтованих житлових програм.

Ключові слова: будівництво, державний бюджет, житлова політика, іпотека, інвестиції, кошти, кредит, соціальна програма, ринок житла.

Актуальність проблеми. Вирішення житлової проблеми є одним із важливих соціальних пріоритетів держави, реалізація якого неможлива без розроблення дієвих механізмів державної підтримки заходів щодо забезпечення доступності житла та поліпшення житлових умов. Є ряд статей, присвячених аналізу проблем у сфері житлової політики, серед яких можна виділити “Про можливість обвалу ринку житла в Україні”[1], “Про можливі шляхи зниження цін на ринку житла”[2] та “Дослідження ситуації з обвалом ринку житла в Україні на прикладі м. Києва”[3]. Один з авторів провів аналіз передумов, які впливають на ціни продажу житла, та певних закономірностей формування кінцевої вартості житла в Україні. У статтях обережно висловлювалось припущення, що економічні передумови до різкого обвалу цін на ринку житла на тогочасному етапі розвитку цього сегмента економіки відсутні, а в останньому випадку наводили конкретні розрахунки по фактичному зростанню цін. На цій основі робили висновки щодо перспектив розвитку будівельної галузі та можливостей вирішення громадянами України житлових проблем. Незважаючи на те, що будівельники рапортують про стабільний розвиток галузі і, від- 
повідно до звітів Держкомстату, обсяги будівництва житла зросли порівняно з минулим роком, дедалі більш зрозумілим для суспільства стає те, що без державної підтримки переважна кількість громадян нашої країни не зможе поліпшити свої житлові умови. 3 огляду на це, актуальним є аналіз можливих форм і засобів державної підтримки реалізації громадянами України права на житло, а також визначення пріоритетних напрямів використання бюджетних коштів для вирішення цього завдання.

За класичною теорією криз, процес розширення грошового обігу і великих вкладень завжди закінчується катастрофою. Відповідно до теорії перенагромадження, в таких ситуаціях економіка або галузь втягується в довгі обхідні методи виробництва, які неможна безперервно зберігати. Протягом певного часу банківські позики, що зростають, дають можливість підприємцям здійснювати виробництво за допомогою нових обхідних методів, але рано чи пізно (чим пізніше це відбувається, тим гірші результати) стає зрозуміло, що доповнення структури виробництва новими ланками не може бути завершене, і роботу над уведенням нових, але незавершених обхідних процесів, слід перервати. Інвестиційний бум зазнає краху, й велика частина вкладеного капіталу втрачається [4].

$\mathrm{Bce}$, що до цього часу робилося у сфері будівництва житла, можна однозначно трактувати як застосування обхідних методів. Як наслідок, маємо збільшення кількості недобудованих житлових будинків, істотне скорочення платоспроможного попиту на житло, вкрай обережне ставлення населення до залучення кредитних коштів для придбання та, особливо, для будівництва житла.

Отже, метою даної статті є формування пропозицій щодо розв'язання найбільш актуальних проблем житлової політики та підвищення їі ефективності як для держави, так і для громадян України.

Виклад основного матеріалу. Останнім часом змінилося й ставлення суспільства до нерухомості як до засобу нагромадження капіталу. Значною мірою на це вплинули зміни законодавчої бази протягом останніх кількох років. Зокрема, Податковий кодекс України містить тепер статтю 265 "Податок на нерухоме майно, відмінне від земельної ділянки" [5], а Закон України "Про державну реєстрацію речових прав на нерухоме майно та їх обтяжень” передбачає створення єдиного Державного реєстру прав [6].

Наведені вище зміни до законодавства заклали основу для розмежування житла на власне і комерційне. Тобто житло, яке громадяни отримують або придбавають для власного проживання, буде відділене від житла, яке фізичні і юридичні особи придбавають 3 метою отримання прибутку. Для цього не обов’язково проводити складні дослідження, а достатньо порівняти два записи - про власника житла і про осіб, які зареєстровані в цьому житлі. В разі збігу цих записів житло без сумнівів придбано для власного проживання. В інших випадках досить легко можна вирахувати імовірність комерційного використання такого житла, наслідком якого має бути відрахування відповідних коштів до державного або місцевого бюджетів у вигляді податків.

Зауважимо, що функція нерухомості як засобу нагромадження капіталу є надзвичайно важливою у функціонуванні ринку житла в Україні через ряд особливостей. Маючи практично нерозвинений фондовий ринок та обмежений обіг цінних паперів, українці залишаються перед вибором відкриття депозитного банківського вкладу в будь-якій валюті або перетворення грошей у іншу форму капіталу. Досить часто приватні особи та організації використовують житло як один із інструментів виведення капіталу з обігу та перетворення його на певний страховий фонд (своєрідна ерзац-валюта). Операції придбання житла з наступним продажем до цього часу мали на меті збереження капіталу за несприятливих умовах ведення бізнесу. Частина підприємців зробила операції з нерухомістю основним джерелом доходів, проте 
останнім часом прибутковість такого бізнесу падає, а ризики зростають, і тому варто очікувати відчутне скорочення кількості суто спекулятивних операцій на ринку житла.

Другою складовою загальної тенденції до скорочення спекулятивних операцій з купівлі-продажу житла стало запровадження безготівкового порядку розрахунку за придбане житло, що практично унеможливить використання коштів, отриманих у “тіньовому” секторі. Так, відповідно до змін до частини 3 статті 1087 Цивільного кодексу України “граничні суми розрахунків готівкою для фізичних та юридичних осіб, а також для фізичних осіб-підприємців відповідно до цієї статті встановлюються Національним банком України" .

Загальна концепція цього нововведення спрямована на зниження можливостей використання “тіньових" доходів та збільшення податкових надходжень від доходів. Проте запровадження цього порядку розрахунків може мати достатньо суттєвий вплив на ринок житла.

Отже, з одного боку, сфера застосування житла як інструмента нагромадження капіталу істотно втрачає свою привабливість, з другого - можливості населення, яке потребує поліпшення своїх житлових умов, скорочуються. Зазначене обумовлює загальні тенденції щодо суттєвого скорочення коштів, що надходитимуть у сектор будівництва житла у найближчі 3-5 років. За дуже орієнтовними розрахунками таке скорочення може скласти 25-30\% протягом першого року з тенденцією до подальшого зменшення протягом наступних двох-трьох років ще на 3-5\% щорічно. Таким чином, до кінця 2015 р. загалом обсяг коштів скоротиться на 30-40\% порівняно з показниками 2011 року. За песимістичним сценарієм загальне скорочення надходжень коштів за цей період може перевищити десять мільярдів гривень. При цьому слід враховувати, що скорочення буде відносним. У разі високих темпів інфляції номінальний обсяг коштів, які надійдуть у будівництво житла, може навіть зрости.

Вихід із ситуації уявляється досить простим - значне зниження вартості іпотечних кредитів. Так, зниження вартості кредитів з рівня 22-28 до рівня 11-14\% у національній валюті призвело б до значного розширення кола потенційних позичальників і припливу грошей у сектор будівництва житла, оскільки потреба у житлі в Україні сьогодні є однією з найвищих серед країн-сусідів. Але прості рішення - не для українських реалій. Просто так, помахом руки знизити вартість іпотечних кредитів у період активної фази економічної кризи банки не можуть (відсутність довгих депозитів, нестабільність світової економіки, високі ризики неповернення раніше виданих кредитів, високі інфляційні очікування тощо). Держава теж не може в директивному порядку примусити комерційні банки знизити ставки іпотечного кредиту, а необхідних ресурсів для широкомасштабної підтримки програми за рахунок державного бюджету немає.

У цьому контексті достатньо привабливими уявляються програми будівництва житла соціального спрямування ("Житло для молоді", ”Доступне житло”, ”Житло для військових", ”Власний дім" тощо). У 2012 р. програма “Доступне житло” набула нового подиху: бажаючим придбати житло було запропоновано отримання кредиту на 15 років під відсоткову ставку $16 \%$ за умов компенсації за рахунок Державного бюджету 13\%. При цьому, перший внесок мав складати $25 \%$ від суми кредиту, а площа квартири відповідати таким характеристикам: для одинаків - на рівні 40 кв м, для родини з 3-х і більше осіб - на рівні 58 кв м.

Водночас привабливими ці програми є лише на перший погляд. На широке їх розгортання годі й сподіватися з огляду на такі фактори:

- у державному бюджеті постійно не вистачає коштів для стабільного щорічного прогнозованого фінансування всіх бюджетних програм, що обумовлює високі ризики для потенційних учасників програм пільгового отримання житла;

\footnotetext{
${ }^{1}$ Цивільний кодекс України (Відомості Верховної Ради України (ВВР), 2003, №№ 40-44, ст.356).
} 
- збільшення державної підтримки на реалізацію таких житлових програм з року в рік внаслідок необхідності виконання взятих у певному році зобов’язань протягом тривалого періоду (10-15 років) створює загрозу фінансовій стабільності і $€$ не реальним за сучасних умов розвитку України;

- занадто великим ризиком у виконанні програм доступного житла є умова щодо купівлі житла у недобудованих будинках при відсутності відповідальності забудовників перед інвесторами за своєчасне введення будинку в експлуатацію.

Як і прогнозувалось, оновлена програма доступного житла не виправдала очікування iï ініціаторів. Станом на жовтень 2012 р. за цією програмою видано лише 606 кредитів на загальну суму 142,05 млн. грн. Для виправлення ситуації уряд запропонував переорієнтувати цю програму на надання житла у лізинг на таких умовах: отримання житла (двокімнатної квартири площею близько 50 кв м) у фінансовий лізинг на 12-15 років під 3\% річних (перший внесок 15\%). За розрахунками Міністерства інфраструктури у цьому випадку громадяни мають платити за квартиру близько 2000 грн. на місяць (без комунальних послуг).

Чи можуть такі підходи істотно зрушити ситуацію з забезпеченістю громадян України житлом, і чи є оптимальним таким чином витрачати бюджетні кошти?

На нашу думку, ні. Й головною помилкою у виборі державою форм та засобів державної підтримки реалізації права громадян України на житло є ідеологічна. А саме - орієнтація на те, що таке право можна забезпечити лише шляхом набуття права власності на житло навіть для тих родин, які не мають ані фінансових можливостей, ані бажання бути власниками. Статтею 13 Конституції України визначено, що власність зобов'язує. Однак, значна частина й сьогоднішніх власників безоплатно приватизованих квартир не розуміють своєї відповідальності по відношенню до житла і не готові до неї. Зазначене вже створило дуже серйозні проблеми з обслуговуванням багатоквартирних житлових будинків. Обмежене застосування наявних механізмів схвалення колективних рішень у багатоквартирних житлових будинках на сьогодні є найбільшим гальмом у реформуванні ЖКГ.

Між тим, у переважній більшості країн світу власниками житла є невелике коло громадян, а саме ті, хто має сталі та достатньо високі доходи і свідомо підходить до придбання житла у власність, розуміючи, що власність передбачає не лише певні права, а й обов’язки. Переважна більшість громадян користується орендним або соціальним житлом і не має жодного бажання бути власниками житла ( табл.1).

Частка найманого житла в окремих країнах світу*

Таблиця 1

\begin{tabular}{|l|c|c|}
\hline Країна & Усього найманого житла, \% & Соціальне житло до житлового фонду, \% \\
\hline Швейцарія & 69 & 14 \\
\hline Нідерланди & 48 & 38 \\
\hline Данія & 45 & 20 \\
\hline Німеччина & 59 & 30 \\
\hline Франція & 38 & 16 \\
\hline Великобританія & 31 & 21 \\
\hline Фінляндія & 28 & 14 \\
\hline США & 33 & - \\
\hline
\end{tabular}

*Джерело: http://www.iut.nu/(Міжнародна спілка наймачів житла) - 2005 рік 
А якщо розглянути ситуацію у великих містах, то орендне житло там розповсюджено ще ширше (табл.2). І це зрозуміло, оскільки орендне житло в умовах цивілізованого ринку є більш зручним способом розв'язання житлових проблем для молодих сімей, фінансовий і кількісний стан яких постійно змінюється. Крім того, таке житло більш влаштовує мобільні родини.

Таблиця 2

Частка найманого житла у окремих містах світу

\begin{tabular}{|l|c|}
\hline Місто & Усього найманого житла, \% \\
\hline Женева & 85 \\
\hline Амстердам & 83 \\
\hline Копенгаген & 50 \\
\hline Берлін & 90 \\
\hline Лондон & 41 \\
\hline Гельсінкі & 47 \\
\hline Нью-Йорк & 70 \\
\hline
\end{tabular}

*Джерело: http://www.iut.nu/(Міжнародна спілка наймачів житла) - 2005 рік

В Україні на сьогодні немає цивілізованого ринку орендного житла, власником якого могла би бути держава або органи місцевого самоврядування. Взагалі не існує такого поширеного у світі фонду житла, як дохідне житло (приватні багатоквартирні будинки, квартири в яких здають в оренду). Лише на папері є такий житловий фонд, як “соціальне житло”, створення якого передбачено Законом України “Про житловий фонд соціального призначення”, що прийнятий ще у 2006 р. Саме на створення цих фондів, на нашу думку, й мають спрямовуватися кошти державного та місцевих бюджетів, а також частково чи у повному обсязі кошти, отримані за рахунок податку на нерухомість.

Для обгрунтування своєї позиції наведемо деякі розрахунки.

В табл. 3 наведено результати орієнтовних розрахунків на придбання стандартної двокімнатної квартири за наступних вихідних даних: вартість квадратного метра житла прийнята умовно рівною одній тисячі доларів США або восьми тисячам гривень; площа квартири становить 70 кв м (двокімнатні квартири меншої площі, на нашу думку, не відповідають сучасному уявленню людини про якість житла); перший внесок умовно мінімальний - 30\%; період кредитування - 15 років; схема кредитування ануїтетна при фіксованій ставці протягом строку кредиту.

Таблиця 3

Відмінність у обсягах витрат на придбання квартири (грн)

\begin{tabular}{|l|c|c|c|c|}
\hline $\begin{array}{l}\text { Ставка кре- } \\
\text { диту }\end{array}$ & Щомісячні внески & $\begin{array}{c}\text { Плата за користу- } \\
\text { вання кредитом }\end{array}$ & $\begin{array}{c}\text { Загальна вартість } \\
\text { квартири }\end{array}$ & $\begin{array}{c}\text { Зростання вартості при } \\
\text { кредитуванні }\end{array}$ \\
\hline $12 \%$ & 4705 & 454839 & 1014839 & $181 \%$ \\
\hline $16 \%$ & 5757 & 644315 & 1204315 & $215 \%$ \\
\hline $25 \%$ & 8371 & 1114828 & 1674829 & $299 \%$ \\
\hline
\end{tabular}

Джерело: розрахунки авторів 
Відсоткові ставки наведено в таблиці з таких міркувань:

$12 \%$ - ставка, при якій населення може самостійно обслуговувати іпотечні кредити;

$16 \%$ - ставка, задекларована у програмі “Доступне житло”;

$25 \%$ - реальні ставки на ринку іпотечного кредитування на час написання статті.

За даними аналітиків станом на вересень 2012 року, джерела фінансування угод по продажу житла такі: 60-65\% - власні кошти населення, 25-30\% - розстрочка від забудовника і тільки 7-10\% - іпотечне кредитування. У докризовий період, коли відсоткові ставки іпотечного кредитування були нижчими, а рівень доходів громадян - вище ніж зараз, частка іпотечних кредитів становила 75-80\%².

Якщо уявити, що за програмою іпотечного кредитування для підвищення іiї ефективності держава візьме на себе зобов'язання сплачувати різницю між $16 \%$ банківського кредиту і $3 \%$, які сплачуватиме позичальник, то вона має при укладенні ста тисяч подібних договорів щорічно протягом 15 років передбачати в державному бюджеті на компенсацію різниці в кредитах не менше 3,5 мільярдів гривень. При цьому слід зазначити, що якщо на наступний рік після старту програми буде придбано ще 100 тис. квартир, щорічні витрати держави на компенсацію різниці в кредитних ставках будуть вже складати 7 млрд. грн. на рік і т.д.

Порівняємо результати реалізації різних можливих програм забезпечення населення житлом при допущенні, що з державного бюджету на ці цілі щороку витрачається 3,5 млрд. грн. протягом 15 років (табл. 4).

Нижче розглянуто лише два варіанти. Перший - відповідно до умов програми “Доступне житло”. Другий передбачає будівництво державною (муніципальною) компанію за рахунок бюджетних коштів орендного житла, а також за рахунок отриманих від оренди коштів - соціального житла. Варіант зниження відсотків за іпотекою до $12 \%$ не розглядався як такий, що є нереальним найближчими роками.

Програма створення орендного та соціального житла є більш привабливою і для населення, i для держави з огляду на ії обов’язок забезпечити право громадян на житло, і для будівельної галузі, яка має стабільно та прогнозовано розвиватися. Водночас перша програма («Доступне житло») є більш ефектною, дає змогу одномоментно продемонструвати позитивний результат, а у подальшому позитивно впливати лише на банківську систему.

За результатами проведеного дослідження можна зробити такі висновки.

1) Ситуація, що склалася нині на ринку житла, є достатньо складною. 3 одного боку, постійно скорочується платоспроможний попит на житло через погіршення рівня життя населення, підвищення ставок іпотечних кредитів, втрати нерухомістю привабливості як інструмента нагромадження капіталу. 3 другого - роками не вирішуються питання поліпшення житлових умов наших громадян, особливо тих, хто має низькі та середні доходи, підвищується соціальна напруженість у суспільстві, зростає незадоволення житловою політикою держави. За цих умов надзвичайно важливо обрати найбільш ефективну модель державної підтримки у цій сфері, визначивши як певний обсяг бюджетних коштів на реалізацію житлових програм, так і житлові фонди, на створення яких мають виділятися бюджетні кошти, а також форми і засоби бюджетної підтримки.

2 Застройщики строят сегодня за счет собственных средств. Столичная недвижимость 26.09.2012 // http://agent.ua/review/news/26209.html\#ixzz22Crs6Nrh 


\section{Порівняльний аналіз різних варіантів державної допомоги на забезпечення прав громадян на житло}

\begin{tabular}{|l|c|c|}
\hline \multicolumn{1}{|c|}{ Показник } & $\begin{array}{c}\text { Програма } \\
\text { “Доступ- } \\
\text { не житло” }\end{array}$ & $\begin{array}{c}\text { Створення державно- } \\
\text { го (муніципального) } \\
\text { фонду орендного та } \\
\text { соціального } \\
\text { житла }\end{array}$ \\
\hline $\begin{array}{l}\text { Загальний обсяг коштів з державного бюджету (рівними частками про- } \\
\text { тягом 15 років), млрд. грн. }\end{array}$ & 52,5 & 52,5 \\
\hline $\begin{array}{l}\text { Кошти населення, витрачені на придбання /оренду житла (за 15 років), } \\
\text { млрд. грн. }\end{array}$ & 67,7 & 17,6 \\
\hline Всього обсяг коштів на реалізацію програми (за 15 років), млрд. грн. & 120,2 & 70,1 \\
\hline 3 них, спрямовані безпосередньо на будівництво (у будівельну галузь) & $55,9 *$ & $70,1 * *$ \\
\hline 3 них, у банківську сферу (виплата кредитів), млрд. грн. & 64,3 & - \\
\hline Кількість побудованих квартир (од.), у тому числі: & $100000^{* * * *}$ & $125088^{* * * *}$ \\
\hline приватні & 100000 & - \\
\hline орендні & - & 93750 \\
\hline соціальні & - & 31338 \\
\hline Щомісячна оплата (протягом 15 років), грн. & 5750 & 2000 \\
\hline
\end{tabular}

\footnotetext{
Джерело: розрахунки авторів

*у перші два роки реалізації програми

**рівномірно за роками

***для тих, хто оформив кредити у перший рік старту програми

****рівномірно за роками
}

2) На нашу думку, зводити вирішення житлових проблем громадян лише до придбання (надання) житла у приватну власність є помилковим. По-перше, тим самим збільшується “армія” фінансово незабезпечених власників житла, які не готові до цього ані морально, ані фінансово. Тим самим поглиблюються складності з управлінням багатоквартирними будинками, створюються умови для збільшення проблемних кредитів i, відповідно, погіршення фінансової стійкості банків. По-друге, отримання у власність невеличких квартир (50 - 70 кв м) лише тимчасово вирішує проблеми багатьох родин, склад яких з часом змінюється (народжуються діти, створюються нові родини тощо). Водночас наявність у власності таких квартир обмежує свободу пересування людей при виборі роботи, призводить до підвищення транспортного напруження тощо. 3 огляду на зазначене та спираючись на міжнародний досвід, слід замислитися над створенням в Україні цивілізованого ринку орендного житла (як такого, що належить державі та органам місцевого самоврядування, так і приватних дохідних домів), а також - фонду соціального житла, передбачивши для цього джерела фінансування.

3) За відсутності достатніх обсягів бюджетних коштів, що могли би бути спрямовані на поліпшення житлових умов громадян, які цього потребують, не є ефективним витрачати бюджетні кошти на створення фондів приватного житла, особливо у формі, передбаченій останньою версією програми “Доступне житло”. У цьому випадку кошти, передбачені для цього у державному бюджеті, фактично будуть спрямовані на розвиток банківської системи і стимулюватимуть пожвавлення будівництва лише на перші рік-два після старту програми. Та після певного пожвавлення будівництва, у середньо- та довгостроковій перспективі спостерігатиметься різке скорочення обсягів його фінансування, що потягне 
за собою банкрутство забудовників, зменшення введення в експлуатацію готового житла та наступне збільшення маси проблемних кредитів у банківській сфері.

Наслідком такого розвитку подій стане подальше падіння довіри приватних інвесторів до об’єктів незавершеного будівництва, що зменшить грошові потоки до цих об'єктів і підвищить попит на вже введене в експлуатацію житло. Нестача грошей у фінансовому секторі призведе до подальшого зростання вартості іпотечних кредитів, що зробить їх менш доступними для більшості потенційних інвесторів. При цьому спостерігатиметься подальше падіння обсягів будівництва і зростання дефіциту житла, невиправдане зростання цін на наявне житло та відповідне зменшення кількості тих, хто має можливість придбати житло за новими цінами. Отже, за такого розвитку подій замість вирішення житлових проблем і здешевлення житла, отримаємо підвищення його ціни і загострення ситуації з забезпеченістю житлом в Україні.

4) Надзвичайно актуальним у ситуації, що склалася, є схвалення концептуальних засад формування державної житлової політики України, визначення фондів житла, які мають розвиватися в країні, у тому числі, за рахунок державної підтримки; формування відповідних бюджетних механізмів [7]. Слід повернутися до відхиленого Верховною Радою України закону про основи державної житлової політики, схвалення якого й досі передбачене Загальнодержавною програмою реформування та розвитку житлово-комунального господарства на 2009-2014 pp. Зазначеним проектом закону було передбачено розроблення єдиної Державної житлової програми, яка й мала б передбачити першочергові напрями бюджетної підтримки реалізації конституційного права громадян України на житло, джерела та механізми ії фінансування.

\section{Джерела}

1. Манцевич Ю.М. Про можливість обвалу ринку житла в Україні // Економіка України. - 2007. - №7. - С. 81-87.

2. Манцевич Ю. М. Про можливі шляхи зниження цін на ринку житла // Економіка України. - 2008. - № 3. - С. 76-83.

3. Манцевич Ю.М. Дослідження ситуації з обвалом ринку житла в Україні на прикладі м. Києва // Економіка та держава. - 2009. - № 5. - С. 15-18.

4. Хаберлер Г. Процветание и депрессия: теоретический анализ циклических колебаний: [пер. с англ.] / Г. Хаберлер. - Чел.: Социум, 2005. - 474 с.

5. Податковий кодекс України (Відомості Верховної Ради України (ВВР), 2011, N 13-14, N 15-16, N 17, ст.112).

6. Закон України про державну реєстрацію речових прав на нерухоме майно та їх обтяжень (Відомості Верховної Ради України (ВВР), 2004, N 51, ст.553).

7. Запатріна I.В., Кучеренко I.М., Кучеренко О.Ю. Житлова політика України: сучасність і майбутнє. - Видавничий центр Спілки власників житла України. - 2012. - 302 с.

МАНЦЕВИЧ Ю. Н., ЗАПАТРИНА И.В.

\section{РАЗВИТИЕ ГОСУДАРСТВЕННОЙ ПОДДЕРЖКИ ЖИЛИЩНЫХ ПРОГРАММ В УКРАИНЕ}

Решение жилищной проблемы является одним из наиболее важных социальных приоритетов, осуществление которых невозможно без развития эффективных механизмов государственной поддержки мер по обеспечению доступности жилья и улучшения жилищных условий. 
Отношение к недвижимости как к средству накопления капитала постепенно изменяется. Падает рентабельность связанного с недвижимостью бизнеса, возрастают риски и, как следствие, уменьшается часть предпринимателей, у которых недвижимость являлась основным источником доходов. Это обстоятельство во многом обуславливает тенденцию значительного сокращения числа чисто спекулятивных операций на рынке жилья. Второй составляющей формирования тенденции к снижению спекулятивных операций купли-продажи жилья стало внедрение порядка безналичных расчетов при его приобретении, которое практически исключает использование средств, полученных в “теневом” секторе. Изменения в законы заложили фундамент для разделения жилищного строительства на жилье для собственных потребностей и коммерческое.

Указанные причины могут привести к значительному сокращению средств, поступающих в сектор строительства жилья в ближайшие 3-5 лет. Предварительные расчеты показывают, что такое сокращение может составить $30-40 \%$.

В статье утверждается, что главная проблема, которую необходимо решить в Украине сегодня для того, чтобы переломить сложившиеся тенденции, - неопределенность форм и инструментов государственной поддержки реализации жилищных прав граждан Украины. Она носит скорее идеологический характер. Государственная политика в этой сфере базируется на том, что решить проблему с улучшением жилищных условий граждан Украины можно только получая жилье в собственность, даже в том случае, если семьи не имеют финансовых возможностей и желания быть владельцем недвижимости.

Авторы на основе анализа зарубежного опыта показывают ошибочность этого подхода и доказывают необходимость сконцентрировать государственную поддержку на строительстве арендного и социального жилья. На долю арендного жилья может приходиться от 25 до $70 \%$ всего жилого фонда, а в столицах большинства развитых стран этот показатель колеблется от 40 до $90 \%$.

Расчеты авторов ясно показывают, что ориентация бюджетной поддержки в жилищной сфере на создание финансово необеспеченных собственников жилья приводит к увеличению стоимости строительства при существующих условиях кредитования более чем в два раза. При этом бюджетные средства оседают главным образом в банковском секторе. Отягчающим обстоятельством реализации предложенной правительством модели решения жилищных проблем является то, что расходы государственного бюджета на программу «Доступное жилье» должны постоянно расти, а объемы жилья по темпам развития будут значительно отставать от роста объемов финансирования. В случае же переориентации бюджетной поддержки на социально ориентированную программу (строительство арендного и социального жилья) с тем же уровнем годовых расходов из государственного бюджета можно построить на 25-30\% больше жилья и сократить стоимость квартир почти в два раза. Эти средства будут использоваться по прямому назначению - для создания социально-ориентированных жилищных фондов и решения жилищной проблемы для тех, кто действительно в этом нуждается.

Ключевые слова: строительство, государственный бюджет, жилищная политика, ипотека, инвестиции, средства, кредит, социальная программа, рынок жилья.

\section{MANTSEVYCH Y.N., ZAPATRINA I.V. \\ DEVELOPMENT OF THE STATE SUPPORT OF THE HOUSING PROGRAMS IN UKRAINE}

Housing problem solving is one of the most important social priorities. This cannot be achieved without developing efficient mechanisms of state support of measures on ensuring affordable housing and housing conditions improvement. The attitude to the real estate changes step by step. The profitability of real-estate related business falls down, the risks increase and, as a result, decreases the share of entrepreneurs who's main source of income is real estate. This circumstance mainly causes the trend of considerable decrease of speculative transactions number at the housing market. The second component of formation of trend to decreasing of speculative transactions on purchase- sale of housing has become introduction of the procedure of non-cash payments when acquired, it makes almost impossible to use funds received in the shadow sec- 
tor. The changes to laws have laid a fundament for housing construction division into commercial housing and housing for personal needs.

The above reasons may result in considerable decreasing of funds coming to the construction sector during the next 3-4 years. Preliminary calculations show that such decreasing may total $30-40 \%$.

In the article it is stipulated that the main problem that has to be solved in Ukraine today in order to change the existing trends - uncertainty of forms and instruments of state support of implementation of housing rights of the citizens of Ukraine. This problem is mostly of ideological nature. The state policy in this field is based on the fact that the housing conditions of the citizens of Ukraine could be improved only by taking the housing as a property, even if the families have no financial capacity and no wish to be the property owners.

On the basis of the analysis of foreign experience the authors show the falsity of such approach and prove the necessity to concentrate state support at construction of rent and social housing. Rent housing may total $25-70 \%$ of the housing fund, in the capitals of the most of the developed countries this ration varies from 40 to $90 \%$.

The authors' calculations clearly show that directing the state support in housing sector to creation of financially unsecured housing owners results in increasing of the construction costs under the current conditions in more than 2 times. At the same time budget funds are settled mostly in banking sector. Aggravating circumstance of implementation of the governmentally proposed model for housing problems solving is that the state budget expenditures for the program "Affordable Housing" shall constantly grow, and the scope of housing in terms of development pace will be far behind the growth in funding. In case of redirecting the budget support to socially oriented program (construction of rent and social housing) having the same level of annual expenditures from the state budget it could be constructed in 25-30\% more housing and the apartment cost could be decreased almost in 2 times. These funds will be used for their direct purpose - for creation of socially oriented housing funds and solving of housing problem for those who actually need it.

Key words: construction, state budget, housing policy, hypothec, investments, funds, credit, social program, housing market

Стаття надійшла до редакції журналу 19.10.2012 p. 